\title{
Consciousness disturbance associated with severe hyponatremia: A case report
}

\author{
Arif Durana, Tarık Ocak ${ }^{\mathrm{a}}$, Ümit Yaşar Tekelioglu ${ }^{\mathrm{b}}$, Hikmet Tekçec, Akcan Akkaya ${ }^{\mathrm{b}}$, Abdullah Demirhan ${ }^{\mathrm{b}}$, Gülali Aktaş ${ }^{\mathrm{d} *}$ \\ ${ }^{a}$ Department of Emergency Medicine, Faculty of Medicine, Abant Izzet Baysal University, Bolu, Turkey \\ ${ }^{b}$ Department of Anesthesia and Reanimation, Faculty of Medicine, Abant Izzet Baysal University, Bolu, Turkey \\ ${ }^{c}$ Department of Nephrology, Faculty of Medicine, Abant Izzet Baysal University, Bolu, Turkey \\ ${ }^{d}$ Department of Internal Medicine, Faculty of Medicine, Abant Izzet Baysal University, Bolu, Turkey
}

\begin{tabular}{ll}
\hline ARTICLE INFO & ABSTRACT \\
\hline $\begin{array}{l}\text { Article History } \\
\text { Received } \\
\text { Accepted }\end{array} 14 / 12 / 2012$ & $\begin{array}{l}\text { Hyponatremia; a serious electrolyte disorder, frequently develops in the elderly and } \\
\text { hospitalized patients with heart failure. Hyponatremia in patients with heart failure is } \\
\text { usually in hypervolemic form characterized by increased total body sodium and water. } \\
\text { However, rarely, hypovolemic hyponatremia associated with actual sodium loss may } \\
\text { occur in the clinical course. We present an extremely hypovolemic hyponatremia case } \\
\text { in a patient with severe heart failure. Serum sodium value of the patient was } 101 \mathrm{mEq} / \mathrm{L} ; \\
\text { which is exceptionally compatible with life. }\end{array}$ \\
$\begin{array}{l}\text { * Correspondence to: } \\
\text { Gülali Aktaş }\end{array}$ &
\end{tabular}

Department of Internal Medicine,

Medical Faculty,

J. Exp. Clin. Med., 2013; 30:89-91

Abant Izzet Baysal University,

Bolu, Turkey

e-mail: draliaktas@yahoo.com

\section{Keywords: \\ Consciousness disturbance \\ Diuretic treatment \\ Hyponatremia \\ Hypovolemia}

\section{Introduction}

A serum concentration of sodium lower than $135 \mathrm{mEq} / \mathrm{L}$ is defined as hyponatremia. An elaborate history and a cautiousphysical examination should be carried out, and basic laboratory tests should be performed in defining the etiology of hyponatremia. Patients are usually asymptomatic unless serum sodium is under $125 \mathrm{mEq} / \mathrm{L}$ (Goh, 2004). Gastrointestinal symptoms such as nausea and vomiting, disorientation, lethargy, seizures or death may occur depending on the severity and occurrence rate of hyponatremia. Severe hyponatremia (a serum concentration of lower than $120 \mathrm{mEq} / \mathrm{L}$ ) can trigger life-threatening neurological complications. Furthermore, rapid correction of severe hyponatremia may lead to osmotic demyelination. Hyponatremia in patients with heart failure is usually in hypervolemic form characterized by increased total body sodium and water. However, rarely, hypovolemic hyponatremia associated with actual sodium loss may occur in the clinical course.
We present an extremely hypovolemic hyponatremia case in a patient with severe heart failure. Serum sodium value of the patient was $101 \mathrm{mEq} / \mathrm{L}$; which is exceptionally compatiblewith life.

\section{Case Report}

A 64 year old woman referred to our clinic with unconsciousness. She had a mitral valve replacement operation history. She has been prescribed combination of diuretics for three years for heart failure. Her medications were as follows: valsartan (160/12.5 mg/day), furosemide (40 mg/day), spironola ctone+hydrochlorothiazide $(25 / 25 \mathrm{mg}$ /day).

Her blood pressure at admission was $80 / 40 \mathrm{mmHg}$, heart rate was $120 / \mathrm{min}$, respiration rate was $22 / \mathrm{min}$ and axillary body temperature was 36.8 centigrade degree. On physical examination, she was not edematous, on the contrary, she was significantly dehydrated. Glasgow coma scale was 11 for the patient, and she had muscle weakness $(3 / 5)$ in all 4 extremi- 
ties. Deep tendon reflexes were normal, and no pathologicalreflexes were detected.

The only pathological sign in electro cardiography was sinus tachycardia (120/min). Cardiothoracic index was markedly elevated (0.62) on telecardiography (Fig. 1). Arterial blood gas measurements were as follows: $\mathrm{pH}: 7.54, \mathrm{PaO} 2: 113 \mathrm{~mm}$ $\mathrm{Hg}, \mathrm{PaCO}$ : $27 \mathrm{~mm} \mathrm{Hg}$ and HCO3: 34mmol/L. Biochemical analyses were as follows: Urea: $163 \mathrm{mg} / \mathrm{dl}(10-50 \mathrm{mg} / \mathrm{dl})$, creatinine: $2.31 \mathrm{mg} / \mathrm{dl}(0-1.5 \mathrm{mg} / \mathrm{dl}), \mathrm{Na}: 101 \mathrm{mmol} / \mathrm{L}(135-$ $145 \mathrm{mmol} / \mathrm{L}), \mathrm{Cl}: 70 \mathrm{mmol} / \mathrm{L}(98-110 \mathrm{mmol} / \mathrm{L})$. CT scan of the brain was negative for ischemia or hemorrhage that may describe the clinical symptoms of the patient.

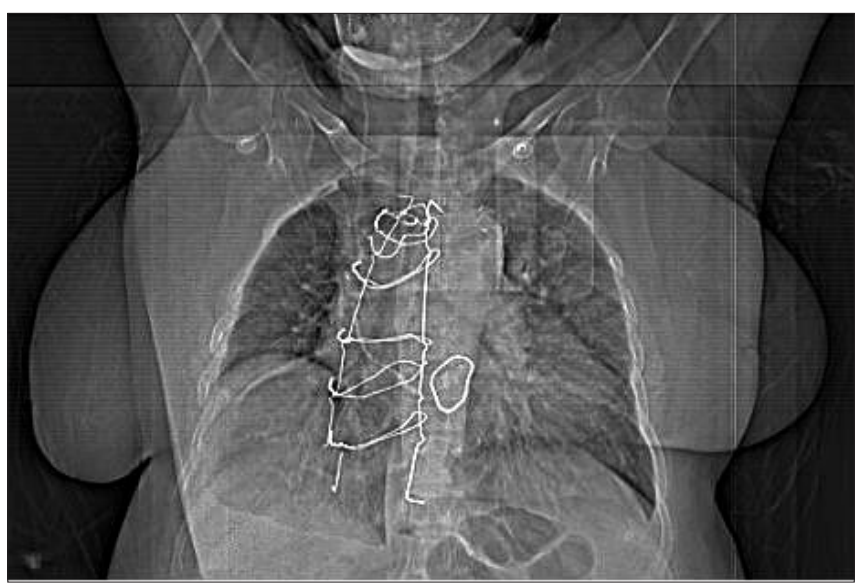

Fig. 1. Chest radiography of the patient

Patient hospitalized in intensive care unit. The patient is diagnosed with hypovolemic hyponatremia because she was dehydrated and treated with high dose diuretics. Although she had heart failure, central venous pressure was measured as 0-2 cm water. Urinary sodium was $45 \mathrm{mmol} / \mathrm{L}$ in spot urinary test probably due to intensive diuretic treatment. $3 \% \mathrm{NaCl}$ solution infused in $30 \mathrm{ml} /$ hour rate. Serum $\mathrm{Na}$ level corrected with this treatment while monitoring cardiovascular system to avoid volume overload.

On 72th hour of admission, serum $\mathrm{Na}$ and $\mathrm{Cl}$ levels elevated to $135 \mathrm{mEq} / \mathrm{L}$ and $100 \mathrm{mEq} / \mathrm{L}$, respectively. Furthermore, glasgow coma scale became normal and neurologic signs dissolved.

\section{Discussion}

Severe hyponatremia is a tremendously serious clinical condition that may cause death. Several studies have established an association between severe hyponatremia and increased morbidity and mortality rates (Hoorn et al., 2006). Serioussymptoms occur as serum level of sodium reduces under $120 \mathrm{mEq} / 1$ (Yang and Feng, 2012). In the literature, there is a case with hyponatremia who survived with $98 \mathrm{mEg} / \mathrm{l} \mathrm{se}$ rum sodium level 6 weeks after radio iodine (I131) treatment (Woo et al., 2011). In another study, the authors reported the mean sodium level of $114.4 \mathrm{mEg} / \mathrm{L}$ in 40 patients treated with spironolactone and hydrochlorothiazide (Kinoshita et al., 2011). This adverse outcome may be the result of the underlying disease and/or direct complications of hyponatraemia, including cerebral edema in acute hyponatraemia and the osmotic demyelination syndrome (ODS) after rapid correction of chronic hyponatremia (Hoorn et al., 2006). Hyponatremia is frequently associated with neurological disease, neurosurgical procedures, and use of psychoactive drugs (Bhardwaj, 2006). Symptoms of hyponatremia are primarily neurologic, and they develop on the basis of the severity and, particularly, the rate of the change in the serum sodium concentration. Patients with hyponatremia and hypernatremia may also have complaints related to concurrent volume depletion and possible underlying neurologic diseases that predispose to the electrolyte abnormality.

The clinical consequences of hyponatremia are due to water moving from hypo-osmolar extracellular fluid into the relatively hyperosmolar interior of the cell. This water movement can cause progressive cerebral edema, resulting in a spectrum of signs and symptoms from headache and ataxia to seizures and coma (Vaidya et al., 2010).

Morbidity and mortality rates in hyponatremic patients are related to the rate of correction of hyponatremia. Both in adequate treatment of acute and sever hyponatremia and rapid correction of chronic hyponatremia with excess sodium are risky and may cause death or irreversible brain damage. Demyelinization due to inadequate treatment of hyponatremia usually occurs in pontin cells as they are extremely sensitive to changes in osmolarity (Akman and Güven, 2001). Correction rate of hyponatremia should be $0.5-1.5 \mathrm{meq} / \mathrm{l} / \mathrm{h}$ (Kinoshita et al., 2011). Compatible with literature, serum sodium levels of the patient gradually raised without causing irreversible neurological damage.

In conclusion, we think that the etiology of the hyponatremia should be defined before appropriate treatment. Sometimes many etiological causes act together and sometimes initial diagnosis may be wrong. Despite present case was a patient with heart failure, clinical findings were compatiblewith hypovolemic hyponatremia (due to diuretic treatment). A detailed history and cautious physical examination usually reveal the etiology. We think that physicians should be aware of hyponatremia especially in patients with unconsciousness, who have a normal CT scan of the brain. Over treatment with hypertonic saline solutions must be avoided especially in thefirst 24 hours of treatment.

\section{REFERENCES}

Akman, S., Güven, A.G., 2001. Hiponatremi: Klinik değerlendirme ve tedavi. Türk Nefroloji Diyaliz ve Transplantasyon Dergisi. 10, 68-72. Bhardwaj, A., 2006. Neurological impact of vasopressin dysregulation and hyponatremia. Ann. Neurol. 59, 229-236.

Goh, K.P., 2004. Management of hyponatremia. Am Fam Physician. 69, 2387-2394.

Hoorn, E.J., Lindemans, J., Zietse, R., 2006. Development of severe hyponatraemia in hospitalized patients: Treatment-related risk factors and inadequate management.. Nephrol. Dial. Transplant. 21, 70-76.

Kinoshita, H., Kobayashi, K., Yaguramaki, T., Yasuda, M., Fujiki, K., Tomiyama, J. Yakushiji, F., 2011. Losartan potassium/hydrochlorothiazide (Preminent ${ }^{\circledR}$ ) and hyponatremia: Case series of 40 patients. Hum. Exp.Toxicol. 30, 1409-1414.

Vaidya, C., Ho, W., Freda, B.J., 2010. Management of hyponatremia: Providing treatment and avoiding harm. Cleve Clin. J. Med. 77, 715726.

Woo, Y.C., Kang, H., Cha, S.M., Jung, Y.H., Kim, J.Y., Koo, G.H., Baek, C.W., 2011. Severe intraoperative hyponatremia associated with the 
absorption of irrigation fluid during hysteroscopic myomectomy: A case report. J. Clin. Anesth. 23, 649-652.

Yang, B.J., Feng, L.M., 2012. Symptomatic hyponatremia and hyperglycemia complicating hysteroscopic resection of intrauterine adhesion: A case report. Chin. Med. J. (Engl). 125, 1508-1510. 